\title{
A Third Place for the Law Library: Integrating Library Services with Academic Support Programs*
}

David C. Walker ${ }^{\star \star}$

This article provides a brief history of the evolution of legal education in America, examining the roles of both law libraries and academic support programs. It then offers suggestions for ways to integrate library services with academic support services.

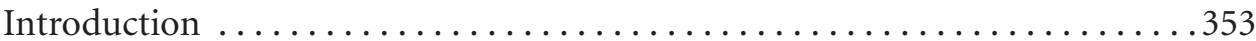

The Evolution of American Legal Education ........................354

The Birth of the Academic Support Program ........................ 357

The Law Library's Role in American Law Schools..................... 360

A Place for the Law Library in Academic Support Programs.............. 362

Academic Support Programs and Libraries as Collections ..............363

Academic Support Programs and Libraries as Places................ 365

Academic Support Programs and Libraries as Collections of Services...... 366

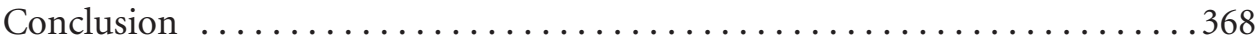

\section{Introduction}

I1 Things change. Though it may seem that American legal education has remained in a perpetual state of Socraticism, it was not always that way. While American legal education has a long history of producing self-learners ${ }^{1}$ (with law libraries assisting them by providing access to print resources), a trend is afoot to move away from self-learning in law. This trend has been aided by the rise in academic support programs, which serve to guide students through the process of learning by converting information into knowledge. The academic law library as an institution has a place in those programs. After all, law libraries have always been treasuries of legal information. Providing access to legal information is but the first step toward helping students learn the law.

I2 The conversion of information into knowledge is a process of internalization. ${ }^{2}$ While some students seem to have an innate ability to perform this conversion,

* @ C David C. Walker, 2013. I would like to thank Jacob Bagget for his research assistance, and Jordan Jefferson, Charles MacLean, and Ann Long for their feedback on this article.

** Director of Lawyering Skills \& Academic Success Programs and Assistant Professor of Law, Lincoln Memorial University Duncan School of Law, Knoxville, Tennessee.

1. The term "self-learning" refers generally to the ability to learn on one's own. Magdalena Mo Ching Mok \& Yin Cheong Cheng, A Theory of Self-Learning in a Networked Human and IT Environment: Implications for Education Reforms, 15 InT'L J. Educ. Mgmt. 172, 173 (2001).

2. See Thomas H. Davenport \& Laurence Prusak, Working Knowledge: How Organizations Manage What They Know 5 (2000). 
others require guidance to learn to internalize legal information so that it becomes knowledge of the law. The professor of law was the original guide to that process. Early American law professors were usually not much more than lecturers. The next breed of professors were inquisitors, guiding law students through the process of knowledge internalization through questioning. However, neither the lecture nor the inquisition has always been adequate to ensure that law students are able to engage in the internal process of turning legal information into knowledge. Consequently, the academic support professional has arisen as the most recent guide to the process of learning the law. These individuals serve to teach students the process of converting information into knowledge.

I3 While academic support programs ${ }^{3}$ have become more or less standard in law schools during the twenty-first century, they are constantly changing shape. Law librarians can take advantage of this to reinvent and reposition themselves in the legal academy and, in doing so, add new value to legal education. Currently, law librarians guide students through the process of acquiring legal information; working with academic support programs would allow them to take the next step and guide students in converting that information into legal knowledge.

\section{The Evolution of American Legal Education}

I4 Legal education in colonial America required lawyers to be self-learners. ${ }^{4}$ Students would devote time simply to reading the law prior to being admitted to practice..$^{5}$ One of the main problems readers faced, however, was access to an adequate collection of law books. ${ }^{6}$ After all, in order to read the law, one needed access to its sources. Fortunately for some aspiring lawyers, two alternatives to self study existed, and both provided students with access to the sources of law, though neither was without drawbacks. ${ }^{7}$ The first alternative was to study at the Inns of Court in England, which was burdensome, as it required transatlantic travel. ${ }^{8}$ The second alternative was to serve as apprentice to an attorney. ${ }^{9}$

I5 Under the apprenticeship system, an apprentice would pay a fee to the attorney for whom he apprenticed. ${ }^{10}$ In exchange, the apprentice would have access to the attorney's library, offering the opportunity for unsupervised study. ${ }^{11}$ While

3. Academic support programs are known by a variety of names and acronyms, including ASPs, academic excellence programs, academic assistance programs, and academic success programs. For clarity, I refer to all such programs as "academic support programs."

4. See Craig Evan Klafter, The Influence of Vocational Law Schools on the Origins of American Legal Thought, 1779-1829, 37 AM. J. LEGAL Hist. 307, 311 (1993).

5. Karen S. Beck, One Step at a Time: The Research Value of Law Student Notebooks, 91 LAW LiBR. J. 29, 30 (1999). While the duration of time spent on self study varied, Patrick Henry was admitted to the Virginia bar after just six weeks of reading the Virginia statutes and an English legal treatise. $I d$.

6. See Klafter, supra note 4 , at 311.

7. See Mark Warren Bailey, Early Legal Education in the United States: Natural Law Theory and Law as a Moral Science, 48 J. LEGAL EdUC. 311, 314 (1998).

8. Beck, supra note 5 , at 30-31.

9. Id. at 31.

10. See Klafter, supra note 4 , at 311.

11. Id. 
only a few native law texts existed within the new republic, apprentices often read treatises such as Coke on Littleton and Sir William Blackstone's Commentaries on the Laws of England, as well as the cases found within any available reporter volumes. ${ }^{12}$ The bulk of early American law students' time, even while apprenticing, was often spent reading in solitude. ${ }^{13}$ Due to time and economic constraints, many lawyers lacked the incentive to train their apprentices beyond what they needed for the cases at hand. ${ }^{14}$ In some instances apprentices were relegated to performing menial work. ${ }^{15}$ Thus, for many postcolonial law students, the apprenticeship system provided little assistance with their legal education except to allow them access to private libraries. ${ }^{16}$

I6 Proprietary law schools, such as the Litchfield Law School in Connecticut, began to emerge in the early years of the republic, affording law students the opportunity to attend lectures and to read from broader collections of legal texts. ${ }^{17}$ The lectures themselves, typically given by a sole professor, provided some direction to students as to what materials they should read. ${ }^{18}$

I7 The Litchfield Law School, founded in 1784, was successful for nearly fifty years, ${ }^{19}$ and eventually a number of universities opened their own programs in legal education. ${ }^{20}$ Like the private law schools, these programs, including those at Yale, Harvard, Dartmouth, Columbia, and the University of Maryland, typically consisted of one lecturing professor who would also hold frequent moot courts. ${ }^{21}$ Most of these legal education programs consisted of lectures, relying on the use of treatises and, to some extent, cases. ${ }^{22}$ The University of Maryland's program employed, along with five other professors of law, Murray Hoffman, whose program was described as essentially one of independent study. ${ }^{23}$

I8 Legal education in the United States was revolutionized when Christopher Columbus Langdell introduced the Socratic casebook method at Harvard in $1870 .{ }^{24}$

12. Steve Sheppard, An Introductory History of Law in the Lecture Hall, in 1 The History of LegAL Education in the United States: Commentaries and Primary Sources 11 (Steve Sheppard ed., 1999).

13. See id. at 9.

14. W. Burlette Carter, Reconstructing Langdell, 32 GA. L. REv. 1, 12 (1997).

15. Id. For example, Joseph Story began reading for the law in 1798 under Samuel Sewell, who was then a member of Congress and, as Story expressed, not a very attentive teacher. Sewell did assign readings to Story, such as Blackstone's Commentaries and Coke on Littleton, before Story took to reading reported cases, and the assigned readings were the majority of the instruction provided. Sheppard, supra note 12, at 9. Story's experience was not atypical. See Klafter, supra note 4, at 312.

16. See Sheppard, supra note 12, at 9-11.

17. Id. at 13 .

18. $I d$.

19. Susan Katcher, Legal Training in the United States: A Brief History, 24 WIs. InT'L L.J. 335, 342 (2006).

20. See id. at 348 .

21. Among the earliest university programs in law were those started by the College of William and Mary in Virginia and Transylvania University in Kentucky. Mark L. Jones, Fundamental Dimensions of Law and Legal Education: An Historical Framework-A History of U.S. Legal Education Phase I: From the Founding of the Republic Until the 1860s, 39 J. Marshall L. Rev. 1041, 1069 (2006).

22. See Sheppard, supra note 12, at 13-20.

23. Katcher, supra note 19, at 351.

24. Sheppard, supra note 12 , at 25. 
While cases had been used to help learn the law since the sixteenth century, ${ }^{25}$ Langdell's method relied primarily on his students' reading of cases, instead of relying on treatises coupled with lectures on black letter law. ${ }^{26}$

I9 Langdell's theory of legal education was based on his belief that law could be understood as a science. ${ }^{27}$ As such, the law library served as the lawyer's laboratory, and appellate cases published in reporters were the materials with which the lawyer would conduct his experiments. ${ }^{28}$ The importance of the law library to Langdell may well have grown from both his fondness for legal research and his position as the librarian of Harvard Law School (which he held while a student). During his tenure, the library was given glowing assessments from the Law School Visiting Committee of the Harvard Overseers. ${ }^{29}$ In any event, Langdell's reliance on primary materials over secondary sources fostered the system of legal education that was to become predominant in American law schools. ${ }^{30}$

I10 Langdell did not lecture students about the meaning of judicial decisions in the larger context of the law. ${ }^{31}$ Instead, he asked his students to read cases and to decide for themselves what the cases meant to the law: ${ }^{32}$

Langdell would ask students to "tell what the facts were, how the litigation developed, what point was at issue, what the court had decided, and the court's reasoning." Langdell would then solicit the students' opinions and reactions to the cases. Finally, Langdell would inquire as to "whether the case followed others which the class had read, or was inconsistent; whether it could be 'distinguished'; and so on."33

In this way, Langdell instituted a new method for "self-learning" in law, which required students to construct the legal forest from the decision trees. ${ }^{34}$ This new method was not without its critics, however. ${ }^{35}$ His students and colleagues, as well as prominent members of the bar, all criticized Langdell's method, ${ }^{36}$ but Langdell persevered, ${ }^{37}$ and his method changed legal education for good. Fifty years after Langdell came to Harvard, the number of university-based American law schools had grown rapidly, and most "emulat[ed] Langdell's Harvard." ${ }^{8}$ While law school curricula, following the development of American law, have expanded into a num-

25. Id. at 24 .

26. Id. at $25-26$.

27. Russell L. Weaver, Langdell's Legacy: Living with the Case Method, 36 VILL. L. ReV. 517, 527-28 (1991).

28. See Katcher, supra note 19, at 357-58.

29. Bruce A. Kimball, Young Christopher Langdell, 1826-1854: The Formation of an Educational Reformer, 52 J. LEGAL EDUC. 189, 225 (2002).

30. Stephen R. Alton, Roll Over Langdell, Tell Llewellyn the News: A Brief History of American Legal Education, 35 OKLA. City U. L. Rev. 339, 341 (2010).

31. Sheppard, supra note 12 , at 26.

32. Weaver, supra note 27 , at 526-27.

33. Id. at 532-33 (quoting Arthur E. Sutherland, The LaW at Harvard: A History of IdeAs and MEN, 1817-1967, at 179 (1967)).

34. See Eric Mills Holmes, Education for Competent Lawyering: Case Method in a Functional Context, 76 Colum. L. Rev. 535, 547-49 (1976).

35. Sheppard, supra note 12 , at 26.

36. Weaver, supra note 27, at 533-34.

37. See id. at 537-39.

38. Alton, supra note 30, at 349-50. 
ber of subjects that were completely unheard of in Langdell's time, the basic ways in which law schools provide instruction to students in the classroom have largely remained static. ${ }^{39}$

\section{The Birth of the Academic Support Program}

I11 The casebook method, at least as it has been employed in legal education, does not automatically provide a student with an understanding of complex legal doctrine or the ability to apply that doctrine to new situations. ${ }^{40}$ Obtaining a legal education is not as easy as reading cases and engaging in classroom dialogue with professors. ${ }^{41}$ The cases contained within the casebook provide individual pieces of information that must be synthesized into a larger, complex system of knowledge. Students must be able not only to identify individual legal rules that are gleaned from dissecting case law, but also to arrive at an understanding of how those individual rules work together.

I12 For example, a student may understand that, in order to prove that a defendant held the requisite intent to commit battery, it must be shown that the defendant either intended the consequences of his conduct or knew with substantial certainty that the consequences would result, but that understanding is not sufficient to demonstrate an overall comprehension of the law of torts. Nor is that understanding enough to demonstrate that the student grasps the law of intentional torts. The student must also recognize the concepts of transferred intent, how intent works in conjunction with the defendant's conduct, and legal causation. The student must be able to differentiate between battery and assault and between battery and negligence. ${ }^{42}$ Finally, the student must be able to apply this understanding of legal concepts to factual situations different from those he encountered in the cases he read. ${ }^{43}$

\$13 Thus, the case method requires students first to be able to dissect judicial opinions and extract relevant information from those opinions. ${ }^{44}$ They must then order the individual concepts in a larger structure, usually by using outlines or flowcharts. ${ }^{45}$ In some cases, they must commit all of this to memory. ${ }^{46}$ Students' "legal understanding and mastery of principles of law" is then evaluated through the law school exam, ${ }^{47}$ where they must be able to spot these issues in factual scenarios,

39. See Lauren Carasik, Renaissance or Retrenchment: Legal Education at a Crossroads, 44 IND. L. REV. 735, 740 (2011).

40. See id. at 750-52.

41. Id.

42. See Deborah A. Schmedemann \& Christina L. Kuntz, Synthesis: Legal Reading, Reasoning, AND WRITING 45 (3d ed. 2007).

43. See id. at 46.

44. See id. at 33.

45. See id. at 42 .

46. See id. at 48.

47. Donald H. Stone, What Law Schools Are Doing to Accommodate Students with Learning Disabilities, 42 S. Tex. L. REV. 19, 38 (2000). 
communicate the relevant legal tests, and explain in detail whether these tests are met and how one would know. ${ }^{48}$

I14 The progression from reading cases to demonstrating competence through the vehicle of an exam comes naturally to some students, but for others it takes time and effort to develop and refine the requisite skills. Thus, it is important that students be shown not only what to learn but how to learn it. ${ }^{49}$ For many, law school is not easy, and Langdell's method requires students to look far beyond the assigned cases. In order to defeat "the sink-or-swim mentality of the traditional law school or the hardscrabble attitude of many lawyers," 50 about thirty years ago law schools began to implement programs to promote success in law school by assisting students who might not otherwise be able to learn and analyze the law.

I15 In response to the fact that some students must make a greater effort to develop the requisite skills for success in law school, academic support programs have expanded in American legal education. ${ }^{51}$ While the structures of such programs differ among law schools, ${ }^{52}$ the ultimate goal of each of them is to provide support to students who are at risk of not being admitted to the bar (which in some cases may be the result of not being able to complete law school). ${ }^{53}$ Some academic support programs aim to increase the retention rate of academically at-risk students, ${ }^{54}$ while others focus purely on bar passage rates. ${ }^{55}$ Some programs target minority students, some target at-risk students, and some target all first-year students. ${ }^{56}$

\16 However, the idea for academic support programs came from outside of the legal academy - the programs began at undergraduate institutions in the late nineteenth century and became more prevalent in the $1930 \mathrm{~s} .{ }^{57}$ These programs focused their attention on students considered to be "academically at risk" and provided support to students in reading and learning skills. ${ }^{58}$ In the 1950 s and 1960s, some academic support programs shifted their focus from purely academic considerations to the emotional needs of students. ${ }^{59}$ At that time, academic support programs also began to target a specific student population, "students of

48. Donald J. Kochan, "Thinking” in a Deweyan Perspective: The Law School Exam as a Case Study for Thinking in Lawyering, 12 NeV. L.J. 395, 405 (2012).

49. See Cathaleen A. Roach, A River Runs Through It: Tapping into the Informational Stream to Move Students from Isolation to Autonomy, 36 ARIZ. L. REV. 667, 682 (1994).

50. Louis N. Schulze, Jr., Alternative Justifications for Law School Academic Support Programs: Self-Determination Theory, Autonomy Support, and Humanizing the Law School, 5 CHARLESTON L. REV. 269, 274 (2011).

51. Id. at 275 .

52. See id. at 278 .

53. Id. at $285-86$.

54. Leslie Yalof Garfield \& Kelly Koenig Levi, Finding Success in the "Cauldron of Competition": The Effectiveness of Academic Support Programs, 2004 BYU EDUC. \& L.J. 1, 5 (2004).

55. Id. at 6.

56. Schulze, supra note 50, at 280.

57. Cynthia Schmidt \& Ann L. Iijima, A Compass for Success: A New Direction for Academic Support Programs, 4 CARdozo Pub. L. Pol’y \& Ethics J. 651, 652-53 (2006).

58. Id.

59. Id. 
color." ${ }^{30}$ Other undergraduate program efforts were begun in the 1960s as an attempt to provide academic counseling to struggling undergraduate students. ${ }^{61}$ These programs, however, assumed that all students could be supported academically in a similar fashion, an approach that often proved to be less than successful. ${ }^{62}$

\$17 Law schools were somewhat late in adopting academic support programs. ${ }^{63}$ In 1968, the ABA Fund for Justice and Education founded the Council of Legal Education Opportunity (CLEO) in order to expand opportunities for minority and low-income students to attend law school. ${ }^{64}$ Thirty years later, Congress passed the Higher Education Amendments Act of 1998, ${ }^{65}$ creating the Thurgood Marshall Legal Educational Opportunity Program, which has been administered by CLEO ever since. ${ }^{66}$ CLEO offers a number of programs, including a six-week Pre-Law Summer Institute in which college graduates attend an on-campus program designed to help them succeed in law school. ${ }^{67}$

$\mathbb{1 1 8}$ Over time, however, law schools began to initiate academic support programs themselves.$^{68}$ A survey of academic support programs published in 2000 reported that of 151 law schools who participated in the study, only fourteen schools did not have any form of an academic support program. ${ }^{69}$ "However, of those fourteen schools that said 'no' to having an academic support program, six also indicated that they did have a support program or two." 70 Some of the programs were aimed at students prior to matriculation, often requiring success in the summer as a prerequisite to admission into the J.D. program. ${ }^{71}$ Other programs were provided during the first year of law school. ${ }^{72}$ Student participation is voluntary in some programs and mandatory in others. ${ }^{73}$ However, virtually all programs "provide assistance to academically at-risk students by helping them acquire the skills necessary to compete better with their more proficient peers." 74 According to the 2000 study, to achieve this goal academic support programs tend to provide one or more of the following services: (1) tutoring and the use of study groups focusing on learning substantive material; (2) academic counseling; (3) mentoring by alumni, faculty, or upper-class students; (4) first-year programs on the fundamentals of studying law and

60. Id.

61. See Schulze, supra note 50, at 274 .

62. Id.

63. Id.

64. Robert C. Downs et al., A Partial History of UMKC School of Law: The "Minority Report," 68 UMKC L. REv. 511, 533 (2000).

65. Higher Education Amendments of 1998, Pub. L. No. 105-244, 112 Stat. 1581.

66. See 20 U.S.C. $\$ 1136$ (f) (2006).

67. See Schulze, supra note 50, at 279.

68. E.g., Ollivette E. Mencer, New Directions in Academic Support and Legal Training: Looking Back, Forging Ahead, 31 S.U. L. Rev. 47, 48 (2003).

69. Richard Cabrera \& Stephanie Zeman, Law School Academic Success Programs-A Survey of Available Academic Support Programs for the New Century, 26 Wm. Mitchell L. Rev. 205, 208 (2000).

70. Id.

71. Id. at 209.

72. Schmidt \& Iijima, supra note 57, at 653.

73. Cabrera \& Zeman, supra note 69, at 209.

74. Garfield \& Levi, supra note 54 , at 4. 
preparation for law school exams; (5) special classes in the first year of law school that provide more individualized attention to students; (6) summer programs that concentrate on preparing admitted law students for matriculation ${ }^{75}$ (7) preadmission programs that make acceptance into the J.D. program contingent upon the successful completion of the program; (8) orientation programs that provide students with an introduction to the law school experience; (9) bar exam preparation courses; and (10) resource libraries that provide students with a collection of study aids. ${ }^{76}$ Some academic support programs employ dedicated academic support faculty or personnel, while others rely on doctrinal or legal writing faculty or upper-class students to provide academic support. ${ }^{77}$ No matter the specifics, law school academic support programs continue to develop and refine their missions and services. ${ }^{78}$ As a consequence, law libraries should consider how they can provide assistance in expanding and improving these programs.

\section{The Law Library's Role in American Law Schools}

I19 To those outside of the library profession, the myriad roles of a law library often go unnoticed. The term law library itself can take on a number of meanings. In one sense, a law library is a collection of legal information resources, ${ }^{79}$ historically consisting of treatises, statutory codes, case reporters, and perhaps early form books. ${ }^{80}$ In the early years of the American Republic, law libraries were typically the private collections of law books owned by individual jurists and practitioners. ${ }^{81}$ However, today the layperson's view of the law library is of a place where legal materials are stored. ${ }^{82}$ In the past decade, some librarians have begun to envision the law library as having a dual role as a place (1) where legal materials are stored and (2) where one goes to study. ${ }^{83}$ In 2008, Blair Kauffman noted that even students in the digital age flock to the Yale Law Library as a place to engage in individual study and research. "[T] he library is what holds the students to the law school. They spend more time in the libraries than they do in the classrooms. They may be in the classroom three hours a day; they may be in the library six to ten hours a day." 84 Richard Danner has explained that law libraries are what architects would refer to as a "third place." ${ }^{85}$ In discussing the renovation of Duke's law

75. These programs usually consist of classes that teach both study skills and substantive law.

Cabrera \& Zeman, supra note 69, at 209-10.

76. $I d$.

77. See Schulze, supra note 50, at 281.

78. Id. at 277 .

79. See Random House Webster's College Dictionary 766 (2001).

80. See Michelle M. Wu, Building a Collaborative Digital Collection: A Necessary Evolution in Libraries, 103 LAW LiBR. J. 527, 530, 2011 LAW LiBR. J. 34, III 7-8.

81. Christine A. Brock, Law Libraries and Librarians: A Revisionist History; or More Than You Ever Wanted to Know, 67 LAW LiBR. J. 325, 326 (1974).

82. See Robert C. Berring, Deconstructing the Law Library: The Wisdom of Meredith Willson, 89 Minn. L. Rev. 1381, 1386 (2005).

83. Richard A. Danner, S. Blair Kauffman \& John G. Palfrey, The Twenty-First Century Law Library, 101 LaW LiBR. J. 143, 145, 2009 LAW LiBR. J. 9, III 10-11.

84. Id. at 145 , 111 .

85. Id. at 144, II 9. Blair Kauffman quoted Danner in explaining the "third place" as "[w]here 
library, Danner noted, "The new library is an open, naturally lighted, pleasant space; the students come to it: they use the carrels, they use the table seating, and they're all over the place, on all floors. And that is what we want." 86

I20 That people go to a law library to study the law (even with their own casebooks in hand) is really a result of the fact that libraries are places where legal materials, which were at one time essential to the study of law, are kept. ${ }^{87}$ However, libraries offer more than just their collections and space.

I21 From the perspective of the modern professional law librarian, a law library can be viewed not just as a collection of information containers (books, databases, etc.), but also as a collection of services offered by information professionals well versed in the language of the law. ${ }^{88}$ Many of these services are unique to librarians; others are not. Among the unique services are the roles that tie librarians directly to the library as both a collection and a place-the services of the librarian as caretaker. ${ }^{89}$ The American Association of Law Libraries (AALL) identifies the following as tasks of law librarians: researching, analyzing, and evaluating the quality, accuracy, and validity of sources; teaching and training; writing; managing; and procuring and classifying library materials. ${ }^{90}$ Librarians acquire information assets (collection development), house and organize those assets (technical services), and provide a system by which those assets can be used by the library's patrons (circulation). ${ }^{91}$ Librarians also assist patrons by facilitating access to the collected information assets (reference and research). ${ }^{92}$ Librarians may also instruct patrons on how to access and use the information assets (teaching). ${ }^{93}$ In fact, AALL has divided the specialized abilities of what have been identified as core competencies for law librarians into six different "specialized competencies": (1) library management; (2) reference, research, and client services; (3) collection development; ${ }^{94}$ (4) cataloging; (5) information technology; and (6) teaching. ${ }^{95}$

I22 Two of these specialties deal directly with services to the library's constituencies: reference, research, and client services, and teaching. Both of these specialties place the academic law librarian in the role of educator when dealing with law

your home is your first place, an office or a classroom is a second place, and social places, like dining halls and lounges and coffee shops and bookstores and libraries are a third place." Id.

86. $I d$. at 145 , II 11.

87. See Michael J. Slinger \& Rebecca M. Slinger, The Law Librarian's Role in the Scholarly Enterprise: Historical Development of the Librarian/Research Partnership in American Law Schools, 39 J.L. \& EDUC. 387, 388 (2010).

88. See Berring, supra note 82, at 1402-03.

89. Linda Will, Synergizing Relationships, Legal Mgmt., Oct. 2009, at 42, 44.

90. Law Library Career Information, AM. Ass'N OF LAW LibraRIES, http://www.aallnet.org/main -menu/Careers/lawlibrarycareers/Careers-in-Law-Librarianship.html (last visited May 4, 2013).

91. See Steven A. Meyerowitz, The Changing Role of the Law Firm Librarian, PA. LAW., May/June 2004, at 28, 28.

92. G. Edward White, Law Librarians, 11 Green BAG 2d 81, 96 (2007).

93. See Vicenç Feliú \& Helen Frazer, Embedded Librarians: Teaching Legal Research as a Lawyering Skill, 61 J. Legal Educ. 540, 547 (2012).

94. A duty that during the nineteenth and early twentieth centuries was reserved for the law school faculty. See Brock, supra note 81, at 345.

95. Competencies of Law Librarianship, AM. Ass'N OF LAW LiBRARIES, http://www.aallnet.org/main -menu/Leadership-Governance/policies/PublicPolicies/competencies.html (last visited May 4, 2013). 
students. ${ }^{96}$ While law librarians' service as teachers is obviously related to the law school's educational role, so too is their provision of reference service. ${ }^{97}$ Academic law librarians are expected to train students to find legal information on their own, thus preparing them for the practice of law. ${ }^{98}$

I23 When it comes to teaching, law librarians have become increasingly more integrated into law school curricula. ${ }^{99}$ The concept of the law librarian as law professor arose in the post-World War II era as a result of the trend of hiring dualdegree librarians. ${ }^{100}$ In 1952, the Association of American Law Schools (AALS) recommended that law librarians be integrated into the faculty. ${ }^{101}$ Faculty status ultimately led to teaching responsibilities for law librarians, ${ }^{102}$ and teaching expectations gradually became more standard. ${ }^{103}$ A 1955 survey indicated that at least forty-nine law school librarians spent from a "minimal amount" to one-third of their time teaching. ${ }^{104}$

I24 Today law librarians are involved in a variety of instructional roles, the most prevalent of which is legal research instruction. ${ }^{105}$ Other librarians teach legal writing ${ }^{106}$ or doctrinal courses. ${ }^{107}$ In many cases, law librarians have credentials equal to those of members of the law school faculty. Accordingly, law librarians should take on law school instructional roles wherever they can. Law librarians are no longer mere "janitor-librarians"; 108 they play an essential role in the training of law students and serve as an integral part of the educational life of American law schools. ${ }^{109}$

\section{A Place for the Law Library in Academic Support Programs}

I25 Law libraries can offer assistance to academic support programs in various ways; three of these are discussed below. First, in the law library's role as a collection of information containers, academic support programs can benefit from working with the library in the arena of collection development. Second, in the

96. See id.

97. See Ann Hemmens, Advanced Legal Research Courses: A Survey of ABA-Accredited Law Schools, 94 LAW Libr. J. 209, 213, 2002 LAW LiBR. J. 17, II 8.

98. Id. at 212, III 5-6. "Legal research is, indeed, a fundamental lawyering skill." Donald J. Dunn, Are Legal Research Skills Essential? "It Can Hardly Be Doubted . . , " 1 PersPeCtives: TeaChing Legal RES. \& WRITING 33, 33 (1993).

99. See, e.g., Feliú \& Frazer, supra note 93, at 556.

100. Brock, supra note 81 , at 348 .

101. Id. at 350 .

102. See Christopher J. Hoeppner, Trends in Compensation of Academic Law Librarians, 1971-91, 85 LAW LiBR. J. 185, 189 (1993).

103. Slinger \& Slinger, supra note 87, at 393-94.

104. A. Elizabeth Holt, Compensation of Law Library Personnel in 1955, 48 LAW LiBR. J. 219, 220 (1955).

105. See Slinger \& Slinger, supra note 87, at 394-95.

106. Jan M. Levine, Voices in the Wilderness: Tenured and Tenure-Track Directors and Teachers in Legal Research and Writing Programs, 45 J. Legal Educ. 530, 536 (1995).

107. See Brock, supra note 81, at 349.

108. See id. at 347.

109. See id. at 396-99. 
library's role as a place, it can function as an academic resource center. Finally, in the library's role as a collection of services offered by information professionals well versed in the language of the law, law librarians can participate directly in academic support.

\section{Academic Support Programs and Libraries as Collections}

I26 One aspect of many academic support programs is the development of resource libraries, which provide students with a collection of study aids. The contemporary catalogs of most academic legal publishers are replete with study aids, including hornbooks; nutshells; subject outlines; flowcharts; DVDs and CDs of recorded legal subject lectures; flash cards; and question and answer books, which provide sample multiple choice, short answer, and essay questions along with sample answers or explanations. As experts in collection development, law librarians can assist academic support programs by identifying available resources and acquiring, organizing, and providing access to them.

I27 Some might object to the acquisition of such study materials, believing that law students should not rely on these resources, or that even if it is proper for law students to use such resources, law libraries should leave it to students to acquire their own copies of them. However, it can be argued that libraries should collect such resources either as part of their traditional collection development plan or because ABA standards may be interpreted as requiring the library to do so.

I28 Most legal study guides typically provide the black letter law. Such black letter law would historically have been found in legal treatises and is similar to what students learned before Langdell's casebook method became part of the legal education landscape. Hornbooks were created in response to the casebook method, which never gave law students answers but, instead, set them adrift on an endless sea of possible legal outcomes. Hornbooks, which are usually written by one or two professors who are subject authorities, focus on helping law students understand the law in a simple, straightforward manner. Over time, hornbooks have become staples of legal research and are often used as secondary legal authority. For example, William Prosser's The Law of Torts has evolved from being a mere study aid that explains what the law is into an outline of what the law should be. ${ }^{110}$ As hornbooks became more complicated, West Publishing Company started issuing its wellknown Nutshell series, which provided explanations of the law in a simpler format than hornbooks. It is now common to find treatises, hornbooks, and nutshells within the walls of the academic law library, all of which are used by law students to help them with their studies. It is therefore not a departure from the norm to suggest that academic law libraries should collect other types of study aids.

I29 Even if the pragmatism of collecting such materials is not convincing, it could be argued that adding such materials to a library's collection is a requirement for accreditation. Standard 601(a) of the ABA Standards and Rules of Procedure for the Accreditation of Law Schools requires a law school to "maintain a law library

110. See Craig Joyce, Review Essay, Keepers of the Flame: Prosser and Keeton on the Law of Torts (Fifth Edition) and the Prosser Legacy, 39 VAND. L. Rev. 851, 852-53 (1986). 
that is an active and responsive force in the educational life of the law school."111 Interpretation 303-3 provides that "[a] law school shall provide the academic support necessary to assure each student a satisfactory opportunity to complete the program." ${ }^{\prime 12}$ This interpretation also implies an obligation for a law school to create and maintain a formal academic support program. Thus, assuming that a formal academic support program has been implemented at a law school, the law library is essentially obligated to acquire resources to meet the demands of the program. The law library should work with the law school's academic support professionals to build a collection that reflects the needs of the academic support program. Even if no formal academic support program has been adopted by the law school, it would be beneficial for the law library to determine what types of academic support resources might benefit its students.

I30 Creating an academic support resource library is not as easy as randomly picking titles from a publisher's catalog, however. Different students learn in different ways, ${ }^{113}$ so a resource library should be varied enough to meet the needs of each type of learner. Collection development librarians should work in conjunction with law school academic support professionals to identify and acquire the relevant resources for a diverse user group. If a law school does not have a formal academic support program, librarians may find it useful to survey student requests or consult with academic support professionals from other institutions.

I131 If they have not already done so, law libraries should create and maintain an exam database that provides access to past exams. Exam databases are immensely beneficial to academic support programs, as they provide examples of students applying their legal knowledge to hypotheticals and other exam questions.

I32 Other considerations for the implementation of a resource library involve the organization of and access to the available material. Some academic support materials are only available in electronic format. For electronic formats, a law library should provide a variety of access points, including through the law library's integrated library system and from its web site or electronic research guides.

I33 With print study guides, there are two basic ways in which materials can be organized: physically shelved in the main collection based on their Library of Congress call number, or organized as a single collection in a separate location, just as reference materials are typically separated from the main collection. While the former method is simpler, there are benefits to creating a special location for study guides. Having a special collection for academic support materials makes it easier for students to locate materials specific to their educational needs. It requires less effort on the students' part to discern which materials are geared toward their educational needs versus materials that are research oriented. As an added bonus, a separate study aids collection helps other library users more easily determine that these materials should not be cited in legal briefs and academic papers.

111. Am. Bar Ass'N, 2012-2013 Standards and Rules of Procedure for Approval of LaW SCHOOLS 43 (2012).

112. Id. at 22 .

113. See generally Martha M. Peters \& Don Peters, Juris Types: Learning Law Through SELF-UNDERSTANDING (2007). 


\section{Academic Support Programs and Libraries as Places}

I34 The Litchfield Law School was located in a one-room building-the classroom and the library were not separate. ${ }^{114}$ While the law school's layout was most likely the result of pragmatic and economic considerations, it illustrates how closely tied learning is to the library in legal education. Although over the years the law library has gradually become a place separate from the rest of the law school, there is a great benefit in closing that gap. If students use the law library as a place to study (a third place), then law schools may do well to install academic support professionals in the library.

I35 Most law libraries hold more than just rows of book stacks. They have tables and chairs to facilitate use of the collection, separate rooms for group study, and distinct sections to better engage users with particular library services, such as reference and circulation. They often have computer labs and lounges. In some instances, law libraries even have coffee bars. Libraries have these things because library users use libraries for particular purposes - to work, to study, to learn. If libraries are centers for learning, it makes sense to have academic support professionals become a part of the library, not only to make them more readily accessible, but also to encourage students to utilize their services.

I36 Integrating the physical aspects of academic support programs and law libraries may be one of the most challenging ways to bring the two departments together, depending as it does upon the configuration of building space. However, there are a number of possible ways to bring the two bodies physically closer.

I37 The ideal way to integrate the two departments in a single physical location would be to provide a separate wing of the library exclusively for academic support programs. In this wing, the library could house academic support staff offices; provide a specific location for the academic support resource collection; and offer separate rooms for a writing lab, an academic support classroom (where academic support professionals can hold classes and workshops), group study rooms, and rooms for student tutoring or mentoring. Unless the law library has a spare wing to allocate to the academic support program, the costs associated with this option likely make it economically infeasible. However, where a law school is considering renovating the library building or erecting a new building, it should consider including a separate wing for the academic support program.

I38 A less dramatic approach would be to use existing space in the library for academic support initiatives or to make minor architectural renovations in cases where physical and economic resources are at the law school's disposal. Thus, instead of creating a separate wing for academic support programs, bringing one or more features of academic support into the library could serve the law school and its students well. For example, academic support faculty offices might be relocated to the library, or group study rooms could be used as tutoring spaces or a writing lab. An even easier idea would be for the law library to provide space in which academic support faculty could hold regular office hours.

114. Lawrence B. Custer, The Litchfield Law School: Educating Southern Lawyers in Connecticut, 2 GA. J. S. LEGAL Hist. 183, 187 (1993). 
\39 By whatever means, law schools should work toward ending the practice of keeping law libraries separate from academic support programs. It may be prudent to begin slowly, perhaps by asking academic support faculty to hold office hours in the library before making them a permanent fixture.

I40 A final way to bring academic support into the library space is not to renovate the building or relocate the personnel but rather to reconsider the role of the law librarian. In some cases, a "physical" integration of academic support into the law library could be accomplished by assigning to law librarians the additional responsibility of academic support. In this way, everyone can stay put. This brings us to the final role libraries and librarians can play in academic support programs.

\section{Academic Support Programs and Libraries as Collections of Services}

I41 Law libraries in their role as a collection of services can be valuable to academic support programs through law librarians themselves. Law librarians possess many of the skills needed to provide academic support to law students. Academic support services are widely process based; that is, the proper role of the academic support professional is to help students develop skills to succeed in law school, which requires students to become competent self-learners in the study of law. ${ }^{115}$ The services of the contemporary public services librarian employed in a law school are also often process based. When providing reference service to a student, a good librarian not only helps the student uncover the information sought but, in doing so, teaches the student the process of uncovering that information. ${ }^{116}$

I42 At its core, the study of law requires that students do three things: (1) acquire legal knowledge; (2) internalize legal knowledge; and (3) apply legal knowledge. ${ }^{117}$ The process of acquiring knowledge begins as soon as students read cases or assigned readings for their law school classes. After acquiring the "initial bite" of knowledge from their readings, students' knowledge is then refined in class through lectures, discussions, and the Socratic method. ${ }^{118}$ However, if the refinement of knowledge does not occur in class, students must seek other ways to refine their knowledge, whether through reading secondary source materials (typically in the form of treatises, hornbooks, and study aids), interacting with other students (typically through study groups), or interacting one-on-one with their professors during office hours. Refinement of knowledge also occurs through the process of exam preparation. Much of the refinement process also occurs outside of the classroom when students prepare course outlines, flowcharts, and other study aids. ${ }^{119}$

115. Ellen Yankiver Suni, Academic Support at the Crossroads: From Minority Retention to Bar Prep and Beyond-Will Academic Support Change Legal Education or Itself Be Fundamentally Changed?, 73 UMKC L. Rev. 497, 500-01 (2004). Academic support professionals are sometimes referred to as "guides on the side." $I d$. at 500.

116. See Slinger \& Slinger, supra note 87, at 404-05. See also Theodora Belniak, The Law Librarian of the Twentieth and Twenty-First Centuries: A Figuration in Flux, 101 LAW LiBR. J. 427, 432-33, 2009 LAW LiBR. J. 24, IIII 21-22.

117. See Dennis J. Tonsing, 1000 Days to the Bar but the Practice of Law Begins Now 12-13 (2d ed. 2010).

118. Id. at 39 .

119. Id. at 72 . 
I43 As knowledge is acquired, it must also be internalized. Course outlines, case briefs, and class notes are tools often used by students to help them recall information. Recorded lectures and flash cards are other tools used by students to internalize information. If students do not actively seek to internalize the knowledge they have acquired, that knowledge will be lost.

I44 The application of knowledge occurs in a number of ways. Most noticeably, students will apply the knowledge they have acquired and internalized in a law school exam. However, most students also need to apply the knowledge they have acquired and internalized on the bar examination. This process of legal education closely matches the lawyering process, where lawyers acquire knowledge though primary and secondary sources of legal information, refine their knowledge through careful deliberation, and apply that knowledge to a client's specific legal problem. At the core of each stage of the process, the law student is engaged in the art of legal analysis.

I45 It is important to note that legal education, at least since Langdell, is inextricably intertwined with the sources of legal authority (or the "oracles of law," as Oliver Wendell Holmes Jr. referred to them ${ }^{120}$ ). Although the bulk of the study of law continues to rely principally on case law, statutes, regulations, and secondary sources are increasingly important. Professional law librarians should be recognized as experts on the sources of legal authority, as they are typically asked to find, organize, deconstruct, and interpret legal authorities. A law librarian's job also quite often involves the ability to conduct legal analysis. The art of legal research generally requires complex legal analysis.

I46 Many academic law librarians (those with law degrees) are products of the very types of institutions that employ them-law schools. Of course, possessing a particular skill set does not necessarily mean that one can pass that skill set along to others. However, many law librarians are indeed capable of passing along the skill sets they acquired in law school and, in some cases, legal practice. Two of the most important skills that most contemporary law librarians possess are reference service and teaching. Both of these skills suggest that law librarians are able to help law students succeed in law school. If a law librarian can teach a student a legal process such as conducting legal research on an individual basis, a law librarian should be able to use the same skills to teach other process-based practices, such as reading and briefing cases, outlining courses, time management, and exam taking.

I47 I am not suggesting that law librarians teach the substance of the law or legal doctrine to law students, but rather that they expand the ways they help students develop the skills essential to the process of learning the law. ${ }^{121}$ Nor am I suggesting that law librarians replace academic support faculty. Instead, I am proposing that law librarians can either supplement the efforts of existing academic support faculty or fill in the gaps where no formal law school academic support program is in place. Based on the skill sets they developed in law school and the particular skill sets utilized in their day-to-day work, many law librarians are just as, if not better, suited to

120. Oliver Wendell Holmes, The Path of the Law, 110 Harv. L. Rev. 991, 991 (1997).

121. I am also not suggesting that law librarians are not competent to teach legal doctrine. 
providing academic support to law students as upper-class law students, who may be formally or informally providing the same support.

I48 Assuming that law librarians are sufficiently qualified to provide academic support, there is still the question of what type of academic support they should provide. The answer depends on the nature of a law school's academic support program, but the role of the law librarian in providing academic support mirrors other roles of the law librarian, including teaching and offering one-on-one mentoring. Thus, law librarians may be well equipped to provide academic support in the form of academic counseling or classroom teaching. In both cases, they are engaged in teaching the process-based skills that law students need in order to succeed in law school. Whether in a classroom setting or on an individual basis, law librarians can pass along the following skills: (1) how to read cases, statutes, and other sources of legal information; (2) how to dissect sources of legal information; (3) how to organize the legal information obtained into devices such as course outlines and flowcharts; and (4) how to manage time. Law librarians can also help students enhance their legal writing and exam-taking skills.

I49 Integrating the law librarian into the academic support program is a winwin situation. Academic support programs receive additional sources of support. Law librarians reap the rewards of helping students develop more process-based skills, and of becoming even more relevant to their institutions. Law students gain greater access to more resources to help them succeed in their academic endeavors. This is not an exhaustive list. Law librarians should continue to assess their skills and propose new ways in which they can provide value to their libraries and institutions.

\section{Conclusion}

\50 Just as law libraries are a "third place" in the law school, academic support is a "third place" for law libraries. In the first place, they serve as repositories of information, and their entrances are gateways to worlds of knowledge. In the second place, law libraries help seekers navigate the labyrinth of information in their quest for knowledge. In a third place, such as in strengthening academic support programs, the law library can be a place where the piers of cognitive bridges are built and reinforced.

151 Though the integration of the academic support program and the law library cannot occur overnight, law libraries that do integrate would be continuing their traditional legal education focus of supporting the self-learner in law. In this third place, law libraries can reinvent themselves and add more value to law schools and those served by legal education institutions. 